\title{
Література
}

1. Дичківська І. М. Інноваційні педагогічні технології : [навч. посіб.] / І. М. Дичківська. - К. : Академвидав, 2004. - 352 с. 2. Дружилов С. А. Обучение и стадии профессиональной компетентности / С. А. Дружилов // Непрерывное образование как условие развития творческой личности. - Новокузнецк : ИПК, 2001. - С. 32-33. 3. Інноваційні пошуки в сучасній освіті / за заг. ред. Л. І. Даніленко, Е. Ф. Паламарчук. - К. : Логос, 2004. - 220 с. 4. Компетентнісний підхід у сучасній освіті: світовий досвід та українські перспективи: [бібліотека з освітньої політики / за заг. ред. О. В. Овчарук]. - К. : «К.І.С.», 2004. - 112 с. 5. Кузьмина Н. В. Акмеология: пути достижения вершин профессионализма / Н. В. Кузьмина. - М. : РАУ, 1993. - 73 с. б. Маркова А. К. Формирование мотивации учения в школьном возрасте : [пособие] / А. К. Маркова. - М. : Просвещение, 1983. - 96 с. 7. Пересторонина И. Л. Особенности формирования профессиональной компетентности будущего учителя при изучении второго иностранного язика / И. Л. Пересторонина // Научное исследование и российское образование: идеи и ценности 21 века: [материалы 6-й междисциплинарной научно-практической конференции аспирантов и соискателей (3-4 апреля 2003 года)] / сост. Н. В. Фанькина. - М. : АПК и ПРО, 2003. - С. 177-181. університету імені Тараса Шевчека

\section{НАВЧАННЯ КУРСАНТІВ ВИЩИХ ВІЙСЬКОВИХ НАВЧАЛЬНИХ ЗАКЛАДІВ ІНШОМОВНОГО ПРОФЕСІЙНО-ОРІЕНТОВАНОГО АУДІЮВАННЯ}

Златніков В.Г. Навчання курсантів вищих військових навчальних закладів іншомовного професійно-орієнтованого аудіювання.

У статті наголошується, що іншомовне спілкування стає важливим елементом професійної діяльності майбутніх офіцерів Збройних сил України; розглядаються особливості навчання курсантів вищих військових навчальних закладів іншомовного професійно-орієнтованого аудіювання. Проаналізовано основні причини, що зумовлюють складність сприймання на слух військової термінології.

Ключові слова: майбутні офіцери, професійно-орієнтоване аудіювання, військова термінологія, емоційно забарвлене мовлення, військова лексика, військовий сленг, нестатутна термінологія.

Златников В.Г. Обучение курсантов высших военных учебных заведений иностранному профессионально-ориентированному аудированию.

В статье подчеркивается роль иноязычного общения в профессиональной деятельности будущих офицеров Вооруженных сил Украины; рассматриваются особенности обучения курсантов высших военных учебных заведений иноязычному профессиональноориентированному аудированию. Проанализированы основные причины сложности восприятия на слух военной терминологии.

Ключевые слова: будущие офицеры, профессионально-ориентированное аудирование, военная терминология, эмоционально окрашенная речь, военная лексика, военный сленг, неуставная терминология.

Zlatnikov V. H. Teaching cadets of higher military educational institutions professionally-oriented listening comprehension.

The paper highlights the role of foreign language communication in the professional activity of the future officers of the Armed Forces of Ukraine; the features of cadets' training of professionally-oriented listening comprehension are considered. The main difficulties of listening comprehension of military terminology are analyzed.

Key words: future officers, listening comprehension, war terms, emotionally coloured speech, soldiers' argot, not according to regulations terminology. 
Процес реформування Збройних сил, розширення участі України в міжнародній миротворчій діяльності зумовлюють зростання вимог до якості володіння особовим складом Збройних сил України (ЗСУ) іноземними мовами.

Особливої актуальності набуває аспект мовної підготовки курсантів вищих військових навчальних закладів. Професійно-орієнтований підхід до навчання іноземної мови майбутніх офіцерів ЗСУ передбачає формування в курсантів здатності до іншомовного спілкування в конкретних професійних ситуаціях 3 урахуванням особливостей професійного мислення.

Окремі аспекти мовної підготовки військовослужбовців висвітлено в наукових доробках В. Балабіна, М. Білана, В. Лісовського (особливості військового перекладу), К. Мамчура (розвиток іншомовної комунікативної компетентності військовослужбовців), С. Сінкевича (формування ціннісного ставлення курсантів вищих військових навчальних закладів до вивчення іноземної мови). Особливості навчання аудіювання майбутніх фахівців розкрито в дослідженнях В. Александрова, О. Бігич, О. Бочкарьової, 3. Корнєвої, С. Медведєвої, Б. Тарнопольського, Л. Черепанової та інших. Але питання формування навичок іншомовного мовлення під час аудіювання військовослужбовців $є$ недостатньо дослідженим.

Розвиток іншомовної комунікативної компетентності як ознаки професіоналізму майбутнього офіцера залежить від удосконалення його здатності до професійноорієнтованого аудіювання.

Мета статті полягає у вивченні особливостей навчання курсантів ВВНЗ іншомовного професійно-орієнтованого аудіювання.

Професійно-орієнтоване аудіювання в дослідженні розглядається як активний творчий процес, спрямований на усвідомлення, розуміння та безпосереднє використання в мовленнєвій практиці інформації аудіоповідомлень із питань професійної (загальновійськової) тематики.

Англомовне військове усне мовлення характеризується широким використанням військової термінології, емоційно забарвлених елементів військової лексики, експресивних виразів, чітких нормативних граматичних форм, скорочень в англійській військовій лексиці, специфічних мовленнєвих зворотів та інших мовних явищ, які важко сприймаються без опори на текст.

Лінгвістичні особливості військової лексики пов'язані з переосмисленням наявних у мові лексем. До лексико-семантичних способів утворення військової лексики належать: метафоричний перенос (hawk «яструб / прихильник війни», milk run «звичайне військове завдання»); метонімічний перенос (blue-on-blue «бомбардування своїх військ/ позиції, зазначені на військових картах блакитним кольором»); звуження значення лексеми (adventure «пригода, авантюра, подія / війна»).

До військової лексики передовсім належать усі слова та словосполучення, що означають військові поняття, тобто поняття, безпосередньо пов'язані зі збройними силами, військовою справою, війною тощо. Крім того, до військової лексики варто віднести науково-технічні терміни, що вживаються спільно з військовими поняттями (наприклад, track «гусениця танка або будь-якої іншої бойової машини на гусеничному ходу») [5].

Однією 3 причин, що зумовлюють складність сприймання на слух військової термінології, $\epsilon$ використання слів та словосполучень, які не позначають власне військові поняття, проте вживаються майже виключно у військовій галузі (наприклад, boondocks «джунглі»; behavior report «лист (солдата) додому»; side arms «столові приладдя»), а також деякі іноземні запозичення, різноманітні жаргонізми тощо.

Особливості англомовного аутентичного мовлення військовослужбовців-носіїв англійської мови пояснюються широким використанням військової лексики, у якій важливе місце відведено військовій термінології та емоційно забарвленим елементам військової лексики і сленгу. Складність сприймання на слух військової термінології 
зумовлюється одночасним використанням як термінології офіційної, яка складається зі статутних термінів, так і нестатутної термінології, що вживається в усній мові військовослужбовців.

Складність сприймання та розуміння військового мовлення зумовлено також тим, що деякі слова, що належали до однієї групи військової лексики, можуть втрачати окремі свої властивості i, навпаки, набувати властивостей, характерних для іншої групи. Наприклад, статутними термінами постали слова mess «клуб-столова», pillbox «довготермінова вогнева споруда», silo «шахтна пускова установка», dud «ракета, що вийшла з ладу», що колись належали до військового сленгу, тобто емоційно забарвлених елементів військової лексики.

Сучасна англійська військова термінологія найбільш інтенсивно розвивається в галузі розроблення нових видів озброєння - передовсім, ракетно-ядерних і космічних бойових систем (orbital weapon «орбітальна зброя»; global missile «глобальна ракета»; silo launcher «пускова споруда шахтного типу»; stratospheric fallout «зараження стратосфери радіоактивними продуктами ядерного вибуху»), радіоелектронних та інших технічних засобів (beam rider guidance «наведення по проміню»; laser range finder «лазерний далекомір»; ambush detection device «(техничний) засіб виявлення засідок»; air cushion vehicle «апарат на повітряній подушці») [1, с. 7].

Значні труднощі виникають під час сприйняття військовослужбовцями авіаційної термінології, зокрема термінології армійської авіації (continuous airborne alert «безперебійне бойове чергування в повітрі»; radar picket aircraft «літак радіолокаційного дозору»; gunship «озброєний гелікоптер»; copter-borne «той, що транспортується гелікоптерами»; aviation battalion «авіаційний батальйон; батальйон армійської авіації»; helilift «транспортування на вертольотах»).

Наявні терміни, що стосуються реорганізації з'єднань сухопутних військ та органів військового управління (strike command «ударне командування»; field army support command «командування тилу армії»; division base «база дивізії»; logistics operations center «центр управління тилом»).

Мовлення військовослужбовців-носіїв англійської мови характеризується широким використанням нової термінології, пов'язаної зі змінами деяких принципових положень (доктрин) у тактиці та оперативному мистецтві (area defense «оборона району; позиційна оборона»; forward edge of the battle area «передній край району оборони»; nuclear safety line «рубіж ядерної безпеки»; spoiling attack «випереджувальний удар; контратака з виходом за передній край»; nuclear environment «умови застосування ядерної зброї, ядерна обстановка»).

Особливо багато термінів відображають поняття так званої «війни незвичайними засобами» (unconventional warfare). Чільне місце посідають терміни, пов'язані з різними питаннями американської військової стратегії (balance of terror «рівновага сил залякування»; massive retaliation «масований контрудар»; brush fire war «місцева війна, локальна війна; бойові дії місцевого значення»; quick-response strategy «стратегія гнучкого реагування»).

Багато нових військових термінів виникло у зв'язку 3 американською агресією у B'єтнамі (enclave «береговий плацдарм; опорний пункт»; strategic hamlet «стратегічне поселення (укріплений населений пункт)»; jungle canopy platform «посадочний майданчик для вертольотів на кронах дерев у джунглях»).

Сучасна військова лексика перебуває в постійному динамічному русі. Особливо це стосується американської військової та військово-технічної термінології, що вона безперервно змінюється за рахунок обмеження функціонування низки слів, зміни значень, безперервного поповнення новими термінами, наприклад, у зв'язку з реорганізацією видів збройних сил, виникненням і розробленням нових видів озброєння й бойової техніки, розробкою нових методів ведення війни [3]. 
Варто наголосити на тому, що надзвичайно велика кількість скорочень широко розповсюджена в усному мовленні військовослужбовців. Так, лексичні скорочення включають усічення (наприклад, sub від submarine «підводний човен», submachinegun «автомат, пістолет-кулемет», bish від bishop має значення не єпископ, а «військовий священик, капелан»), «телескопічні» слова (blends) (наприклад, radome від radar dome «обтічник антени РЛС»), і абревіатури (наприклад, USN - United States Navy «військовоморські сили США», BOSS biological orbiting satellite station «біологічна орбітальна станція», SLAR side-looking airborne radar «літакова радіолокаційна станція бокового огляду», SHAPE Supreme Headquarters, Allied Powers, Europe «штаб верховного головнокомандуючого об'єднаними збройними силами НАТО в Європі», СІС Counterintelligence Corps «контррозвідувальна служба») [4, с. 18].

Крім термінології та скорочень, англійська військова лексика містить емоційно забарвлені слова та вирази. Розрізняються, по-перше, слова та словосполучення широковживані та загальновідомі, і по-друге, вузько вживані та маловідомі.

Емоційно забарвлені елементи військової лексики - це (у більшості випадків) стилістичні синоніми відповідних військових термінів (наприклад, doughboy (просторічне слово) та infantryman (термін) мають значення «піхотинець»).

Загальновідома частина емоційно забарвленої англійської військової лексики складається зі слів та словосполучень, що застосовуються для визначення певних військових понять. Наприклад, поняттю «просуватися» відповідають такі емоційно забарвлені синоніми: to dash; to drive; to forge ahead; to pour; to push; to race; to roll; to spear-head; to steamroll; to surge; to sweep; to thrust тощо. Відтак, використання такої кількості синонімів ускладнює розуміння мовлення військовослужбовців-носіїв мови.

Слова i словосполучення, що позначають поняття «наносити удари, діяти», застосовуються метонімічно для позначення суміжної ознаки цього поняття, а саме «просуватися з боями» (зазвичай з прислівниками або іншими словами, що вказують на напрямок). Наприклад, to crush (forward); to fight one's way forward; to hammer (southward); to knife (ahead); to pound (forward); to slash (slice); to strike (west).

Наведемо кілька прикладів цієї частини емоційно забарвленої лексики: shoot-and-scoot missile «ракета на рухомій пусковій установці»; up-hill struggle «завзятий (важкий) бій»; ding-dong, tug of war «бої з перемінним успіхом»; Doom's Day weapon «термоядерна зброя»; cloak and dagger service «секретна служба»; silent service «підводний флот».

До вузьковживаної та маловідомої емоційно забарвленої частини військової лексики належить лексика літературного походження, розмовна лексика та військовий сленг (специфічна частина емоційно забарвленої частини військової лексики).

В аспекті вживаності військовий сленг можна розподілити на дві частини. Так, перша (порівняно незначна за обсягом) вживається досить широко і $є$ складником просторічної лексики загальнонародної англійської мови. Наприклад, leatherneck «морський піхотинець»; brass hat «генерал»; GI «солдат»; flat top «авіаносець». Друга частина (більша за обсягом) має вузьку сферу вживання, що обмежується переважно збройними силами США і Великої Британії. Наприклад, loot «лейтенант»; in the bucket «в трубці» (відхилення ракет в заданих межах); slick «неозброєний гелікоптер», ankle «займатися стройовою підготовкою», baby «проблема; справа; завдання», base rat «тилова криса, тиловик» [1, c. 308].

Ураховуючи позицію В. Балабіна $[1$, с. 5], вважаємо за необхідне зазначити, що військовий сленг є суттєвим бар'єром двомовної комунікації через поєднання мовних та позамовних чинників утворення військового сленгу. Труднощі розуміння і трансляції лексичного значення одиниць військового сленгу пов'язані з поширеністю й частотністю військового сленгу, недостатньою вмотивованістю багатьох сленгізмів, сферою використання сленгу, чинником актуальності, специфічністю лексико-морфологічного складу, нормативними та стилістичними ресурсами цільової мови в умовах відсутності англо-українських словників військового сленгу. 
Отже, різноманітність і складність словникового матеріалу зумовлюють виникнення певних труднощів у навчанні курсантів професійно-орієнтованого аудіювання, які пов'язані з особливостями подання повідомлень військової тематики та переважанням аудіативних джерел інформації порівняно з аудіовізуальними, необхідністю сприймання «механічного мовлення» (радіопереговори), емоційно забарвлених елементів військової лексики, експресивних виразів, чітких нормативних граматичних форм, скорочень в англійській військовій лексиці, специфічних мовленнєвих зворотів та інших мовних явищ, що важко сприймаються без опори на текст.

Задля семантизації військової термінології та військової лексики доцільно використовувати наочність (наприклад, макети, слайди, малюнки, відеоролики під час вивчення нових видів озброєння), тлумачення військових термінів і опору на рідну мову (у процесі вивчення специфічної військової лексики).

Формуванню в курсантів умінь професійно-орієнтованого аудіювання сприяє активізація навчально-пізнавальної діяльності засобами комунікативного діалогу, ділових та рольових ігор, дискусій.

Bnрава 1. Task: Listen to the text «International Cooperation of the Armed Forces of Ukraine». Using given information prove the importance of participation of Ukraine in peacekeeping operations.

Bnpaвa 2. Task: Listen to the text «The Partnership for Peace». Imagine that you are military reporters. You are present at the briefing concerning the organization of international tactical exercises. According to the work procedure every reporter is permitted to ask only three questions. The reporter decides who will answer the question? Evaluation criteria of questions: exactness, completeness, correspondence to the topic.

Bnрава 3. Task: Listen to the text «The United States Army». Among above mentioned statements try to find those which don't correspond the text. Give the right variant if the statement is false.

Використання в аудіотекстах до наведених вище завдань англійської військової термінології, емоційно забарвлених елементів військової лексики, експресивних виразів, скорочень, специфічних мовленнєвих зворотів сприяють ознайомленню курсантів із лінгвістичними особливостями англійського військового усного мовлення. Водночас, використання ігрових форм навчання на заняттях із військово-спеціальної мовної підготовки забезпечує активізацію навчальної роботи курсантів, дає змогу залучення майбутніх офіцерів до умов реального англомовного середовища.

\section{Література}

1. Балабін В. В. Сучасний американський військовий сленг як проблема перекладу / В. В. Балабін. - К. : Логос, 2002. - 315 с. 2. Бігич О. Б. Методика формування іншомовної компетенції в аудіюванні у студентів мовних спеціальностей / О. Б. Бігич // Методика формування міжкультурної іншомовної комунікативної компетенції: [курс лекцій]. - К. : Ленвіт, 2011. - С. 175-188. 3. Василенко Д. В. Військова лексика англійської мови XX-початку XXI століття / Д. В. Василенко. - Горлівка : Вид-во ГДПІІМ, 2009. - 220 с. 4. Нелюбин Л. Л. Учебник военного перевода. Английский язык. Общий курс / Л. Л. Нелюбин, А. А. Дормидонтов, А. А. Васильченко. - М. : Ордена Трудового Красного Знамени Военное издательство МО СССР, 1981. - 379 с. 5. Судзиловский Г. А. Англо-русский военный словарь / Г. А. Судзиловский, В. М. Полюхин, В. Н. Шевчук и др. - М. : Воениздат, 1987. - 1343 с. 6. Тарнопольський О. Б. Методика навчання іншомовної мовленнєвої діяльності у вищому мовному закладі освіти / О. Б. Тарнопольський. Дніпропетровськ : Вид-во ДУЕП, 2005. - 248 с. 